\title{
Correction to: Binomial nomenclature for virus species: a consultation
}

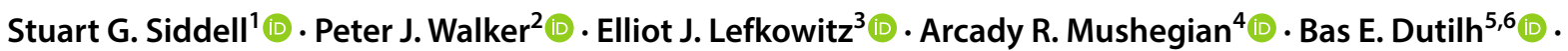

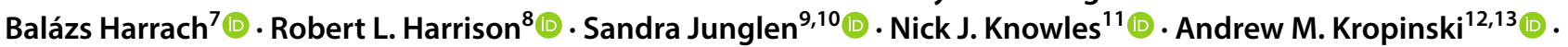

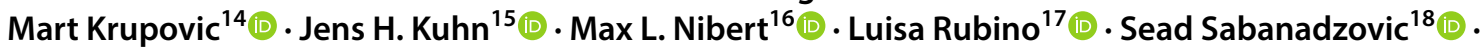

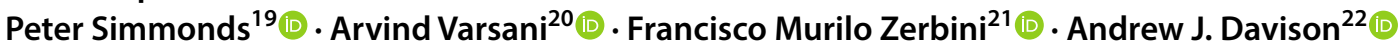

Published online: 17 February 2020

(c) The Author(s) 2020

\section{Correction to: Archives of Virology (2020) 165:519-525 https://doi.org/10.1007/s00705-019-04477-6}

The article Binomial nomenclature for virus species: a consultation, written by Stuart G. Siddell, Peter J. Walker, Elliot J. Lefkowitz, Arcady R. Mushegian, Bas E. Dutilh, Balázs Harrach, Robert L. Harrison, Sandra Junglen, Nick J. Knowles, Andrew M. Kropinski, Mart Krupovic, Jens H. Kuhn, Max L. Nibert, Luisa Rubino, Sead Sabanadzovic, Peter Simmonds, Arvind Varsani, Francisco Murilo Zerbini, Andrew J. Davison, was originally published Online First without Open Access. After publication in volume 165, issue 2, page 519-525 the author decided to opt for Open Choice and to make the article an Open Access publication. Therefore, the copyright of the article has been changed to (C) The Author(s) 2020 and the article is forthwith distributed under the terms of the Creative Commons Attribution 4.0 International License (http://creativecommons.org/licen ses/by/4.0/), which permits use, duplication, adaptation, distribution and reproduction in any medium or format, as long as you give appropriate credit to the original author(s) and the source, provide a link to the Creative Commons license, and indicate if changes were made.

Open Access This article is licensed under a Creative Commons Attribution 4.0 International License, which permits use, sharing, adaptation, distribution and reproduction in any medium or format, as long as you give appropriate credit to the original author(s) and the source, provide a link to the Creative Commons licence, and indicate if changes were made. The images or other third party material in this article are included in the article's Creative Commons licence, unless indicated otherwise in a credit line to the material. If material is not included in the article's Creative Commons licence and your intended use is not permitted by statutory regulation or exceeds the permitted use, you will need to obtain permission directly from the copyright holder. To view a copy of this licence, visit http://creativecommons.org/licenses/by/4.0/.

Publisher's Note Springer Nature remains neutral with regard to jurisdictional claims in published maps and institutional affiliations.
The original article can be found online at https://doi.org/10.1007/ s00705-019-04477-6.

Andrew J. Davison

andrew.davison@glasgow.ac.uk

Extended author information available on the last page of the article 


\section{Affiliations}

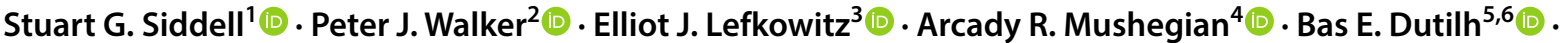

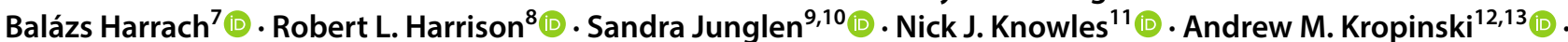

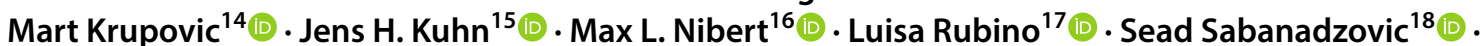

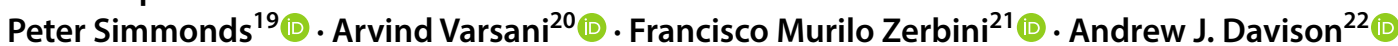

Stuart G. Siddell

stuart.siddell@bristol.ac.uk

Peter J. Walker

peter.walker@uq.edu.au

Elliot J. Lefkowitz

elliotl@uab.edu

Arcady R. Mushegian

mushegian2@gmail.com

Bas E. Dutilh

bedutilh@gmail.com

Balázs Harrach

balazs.harrach@gmail.com

Robert L. Harrison

robert.1.harrison@ars.usda.gov

Sandra Junglen

sandra.junglen@charite.de

Nick J. Knowles

nick.knowles@pirbright.ac.uk

Andrew M. Kropinski

phage.canada@gmail.com

Mart Krupovic

mart.krupovic@pasteur.fr

Jens H. Kuhn

kuhnjens@mail.nih.gov

Max L. Nibert

mnibert@hms.harvard.edu

Luisa Rubino

luisa.rubino@cnr.it

Sead Sabanadzovic

ssabanadzovic@entomology.msstate.edu

Peter Simmonds

peter.simmonds@ndm.ox.ac.uk

Arvind Varsani

arvind.varsani@asu.edu

Francisco Murilo Zerbini

zerbini@ufv.br

1 School of Cellular and Molecular Medicine, Faculty of Life Sciences, University of Bristol, University Walk, Bristol BS8 1TD, UK

2 School of Biological Sciences, The University of Queensland, Saint Lucia, QLD 4072, Australia

3 Department of Microbiology, University of Alabama at Birmingham (UAB), BBRB 276, 845 19th ST South, Birmingham, AL 35294-2170, USA

4 Division of Molecular and Cellular Biosciences, National Science Foundation, 2415 Eisenhower Avenue, Alexandria, VA 22314, USA
5 Theoretical Biology and Bioinformatics, Department of Biology, Utrecht University, Padualaan 8, Room N-604, $3584 \mathrm{CH}$ Utrecht, The Netherlands

6 Centre for Molecular and Biomolecular Informatics, Radboud University Medical Center (Radboudumc), Geert Grooteplein 26, 6525 GA Nijmegen, The Netherlands

7 Institute for Veterinary Medical Research, Centre for Agricultural Research, Hungária krt. 21, Budapest 1143, Hungary

8 Invasive Insect Biocontrol and Behavior Laboratory, USDA-ARS, 10300 Baltimore Avenue, Bldg 007 BARC-West, Beltsville, MD 20705, USA

9 Institute of Virology, Charité-Universitätsmedizin, Corporate Member of Free University Berlin, Humboldt-University Berlin, Berlin, Germany

10 Berlin Institute of Health, Berlin, Germany

11 The Pirbright Institute, Ash Road, Pirbright, Surrey GU24 0NF, UK

12 Department of Food Science, University of Guelph, Guelph, ON N1G 2W1, Canada

13 Department of Pathobiology, University of Guelph, Guelph, ON N1G 2W1, Canada

14 Department of Microbiology, Institut Pasteur, 25 rue du Dr Roux, 75015 Paris, France

15 National Institutes of Health, National Institute of Allergy and Infectious Diseases, Division of Clinical Research, Integrated Research Facility at Fort Detrick (IRF-Frederick), B-8200 Research Plaza, Fort Detrick, Frederick, MD 21702, USA

16 Department of Microbiology, Blavatnik Institute, Harvard Medical School, 77 Ave Louis Pasteur, Boston, MA 02115, USA

17 Istituto per la Protezione Sostenibile delle Piante, CNR, Sede Secondaria di Bari, Via Amendola 165/A, 70126 Bari, Italy

18 Department of Biochemistry, Molecular Biology, Entomology and Plant Pathology, Mississippi State University, 100 Old Hwy 12 Mail Stop 9775, Mississippi State, MS 39762, USA

19 Nuffield Department of Experimental Medicine, University of Oxford, Peter Medawar Building, South Parks Road, Oxford OX1 3PS, UK

20 The Biodesign Center for Fundamental and Applied Microbiomics, School of Life Sciences, Center for Evolution and Medicine, Arizona State University, P.O. Box 874701, Tempe, AZ 85287-4701, USA

21 Departamento de Fitopatologia/BIOAGRO, Universidade Federal de Viçosa, Viçosa, MG 36570-900, Brazil

22 MRC-University of Glasgow Centre for Virus Research, Sir Michael Stoker Building, 464 Bearsden Road, Glasgow G61 1QH, UK 